Jurnal Natur Indonesia 11(1), Oktober 2008: 19-23

ISSN 1410-9379, Keputusan Akreditasi No 55/DIKTI/Kep./2005

\title{
Isolasi dan Karakterisasi Inulinase dari Aspergillus niger Gmn11.1 Galur Lokal
}

\author{
Saryono \\ Jurusan Kimia, Fakultas Matematika dan IImu Pengetahuan Alam, Universitas Riau, Pekanbaru 28293
}

Diterima 27-04-2008 Disetujui 27-09-2008

\begin{abstract}
Inulin is a naturally potential polysaccharide used to produced fructose and fructooligosaccharide. Inulinase known also as B-fructosidase can hydrolise inulin to fructose or fructooligosaccharide. Inulinase production from Aspergillus niger Gmn11.1 isolated from dahlia tubers is conducted using medium containing $1 \%$ inulin and $0,2 \%$ yeast extract. The crude enzyme (filtrate culture) is purified by means of ammonium sulphate salt precipitation, followed by Sephadex G25 gel filtration column chromatography and DEAE cellulose anion exchanger column chromatography. The result indicated that the enzyme had optimum pH and temperature of 4,6 and $45^{\circ} \mathrm{C}$, respectively with incubation time of 15 hours. The $\mathrm{Km}$ and Vmaxs values obtained from this experiment are $20 \mathrm{mg} / \mathrm{ml}$ and 0,769 $\mathrm{mg} / \mathrm{ml} /$ hours, respectively. Whereas the relative molecular weight of inulinase was monitored by SDS PAGE is 63 $\mathrm{KDa}$.
\end{abstract}

Keywords: inulinase, inulin, Aspergillus niger

\section{PENDAHULUAN}

Indonesia merupakan negara tropis yang subur dan kaya akan sumberdaya alam flora, fauna maupun mikroorganisme, yang tentunya dapat dijadikan sebagai obyek penelitian yang cukup potensial. Terkadang, karena banyaknya obyek penelitian yang tersedia masih banyak pula hal-hal yang bermanfaat, namun luput dari pengamatan dan belum tersentuh untuk dijadikan obyek penelitian. Seperti kekayaan alam yang dapat digunakan sebagai sumber enzim yang saat ini aplikasinya semakin banyak diminati. Namun ironisnya sampai saat ini Indonesia masih belum dapat memproduksi sendiri dan sepenuhnya masih tergantung kepada impor. Salah satunya adalah inulinase.

Inulinase adalah enzim hidrolitik yang mengkatalisis reaksi hidrolisis polisakarida inulin menjadi fruktosa dan atau fruktooligosakarida. Saat ini inulinase belum ada tersedia di pasaran dan masih merupakan dalam pengembangan riset. Enzim ini dapat dihasilkan oleh bakteri, jamur, maupun tumbuhtumbuhan. Namun demikian penggunaan enzim mikroba dan aplikasi biokatalisnya banyak mendapatkan perhatian khususnya pada bidang bioteknologi mikroba saat ini (Vandamme \& Derycke 1983).

Telp/Fax: 0811767786

Email:sar_62@yahoo.co.id
Inulin adalah suatu polifruktan yang terbentuk sebagai karbohidrat cadangan pada umbi dan akar beberapa tanaman seperti jerusalem artichoke, chicory, dan dahlia. Senyawa polimer ini memiliki derajat polimerisasi (DP) lebih dari 30 dengan diawali oleh satu molekul glukosa (Worman \& Day 1983; Gupta et al, 1992). Dari ketiga jenis tanaman ini hanya dahlia yang ada di Indonesia. Hasil survei di Lembang Jawa Barat, terungkap bahwa potensi dahlia sebagai bunga potong maupun sebagai bunga pot tidak begitu menguntungkan, karena seperti di Bandung misalnya, harga bunga dahlia dari petani hanya Rp25-35/kuntum. Harga ini hanya untuk dahlia putih yang digunakan sebagai bunga duka cita, sedangkan jenis bunga yang lain tidak begitu laku dijual. Selain itu dahlia pot harganya berkisar antara Rp100-1500/pot.

Hidrolisis inulin menjadi fruktosa dapat dilakukan dengan inulinase. sedangkan hidrolisis parsialnya akan menghasilkan fruktooligosakarida, yaitu suatu oligosakarida yang tidak dapat dicerna oleh usus manusia namu sangat baik untuk menjaga kestabilan flora normal usus dan juga berperan sebagai serat yang larut (soluble dietary fiber). Menurut Pool-Jobel (2005), senyawa polifruktan juga dapat berperan sebagai prebiotik dan memiliki sifat antikarsinogenik. Produksi sirup fruktosa secara konvensional dari pati memerlukan tiga tahap reaksi enzimatik dengan rendemen hanya $45 \%$ sementara produksi sirup fruktosa dari hidrolisis 
inulin hanya memerlukan satu tahap reaksi enzimatik dengan rendemen bisa mencapai 90-95\%. Sirup fruktosa dapat digunakan sebagai pemanis rendah kalori karena fruktosa dua kali lebih manis dari sukrosa dengan organoleptik yang disukai (Nakamura et al, 1995; Roberfroid \& Dezenne, 1998).

Pada kesempatan ini kami telah melakukan isolasi, pemurnian, dan karakterisasi dari enzim inulinase dari Aspergillus niger Gmn11.1. Kapang ini diisolasi dari umbi dahlia yang terdapat di daerah Padang Panjang Sumatra Barat. Strain ini dapat menghasilkan inulinase yang dapat dikembangkan lebih lanjut untuk diaplikasikan pada proses hidrolisis inulin.

\section{BAHAN DAN METODA}

Bahan. Aspergillus niger Gmn11.1 berasal dari koleksi lab. Biokimia FMIPA Univ. Riau Pekanbaru. Inulin (from dahlia tubers), Sephadex G25 dan DEAE selulosa (Sigma Chemical Co), Ekstrak Yeast (Difco). Media tumbuh jamur terdiri dari $2 \%$ inulin dan 0,2\% ekstrak ragi. Untuk media agar ditambahkan $2 \%$ agar dan semua zat kimia yang digunakan adalah pro analisis.

Isolasi inulinase. Aspergillus niger Gmn11.1 ditumbuhkan pada $250 \mathrm{ml}$ media cair dalam erlenmeyer $500 \mathrm{ml}$. Inkubasi dilakukan pada suhu $40^{\circ} \mathrm{C}$ dengan kecepatan agitasi 100rpm selama 5 hari. Inulinase ekstraselular dimurnikan dari filtrat kultur dengan fraksionasi amonium sulfat kemudian dilanjutkan dengan kromatografi kolom gel filtrasi sephadex G25 $(3 \times 70 \mathrm{~cm})$ Fraksi ditampung sebanyak 48 tabung masing-masing $5 \mathrm{ml}$ dengan kecepatan alir $1 \mathrm{ml} /$ menit dan kromatografi kolom penukar ion DEAE selulosa $(2 \times 20 \mathrm{~cm})$. Fraksi ditampung sebanyak 50 tabung masing-masing $3 \mathrm{ml}$, dengan kecepatan alir $1 \mathrm{ml} /$ menit. Pemisahan dilakukan dengan gradien konsentrasi memakai larutan $\mathrm{NaCl} 0,5 \mathrm{M}$ (Alexander et al, 1985).

Penentuan aktivitas enzim inulinase. Aktifitas inulinase ditentukan dengan menghidrolisis larutan inulin $1 \%$ dengan inulinase $(10: 1)$ pada suhu $45^{\circ} \mathrm{C}, \mathrm{pH}$ 4,5 selama 15 jam. Gula pereduksi yang terbentuk ditentukan dengan metoda ortotoluidin, yaitu $1 \mathrm{ml}$ larutan sampel ditambahkan $3 \mathrm{ml}$ pereaksi ortotoluidin (94,5 $\mathrm{ml}$ Asam asetat glasial 5,5 $\mathrm{ml}$ ortotoluidin, dan $0,15 \mathrm{mg}$ tiourea). Campuran dipanaskan dalam air mendidih selama 8 menit dan dinginkan, kemudian diukur dengan spektrofotometer pada panjang gelombang $630 \mathrm{~nm}$ (Zeily et al, 1991).

Penetuan kadar protein. Kadar protein ditentukan dengan metode Lowry et al, (1951) menggunakan BSA sebagai protein standar, dan secara langsung menggunakan spektrofotometer UV pada panjang gelombang $280 \mathrm{~nm}$.

Elektroforesis Gel. Elektroforesis SDS gel poliakrilamid (SDS-PAGE) dilakukan untuk melihat pola dan tingkat kemurnian protein dan penetuan berat molekul enzim. Elektroforesis dijalankan dengan memakai bufer Tris glisin $\mathrm{pH} 8,3$ dengan arus konstan $6 \mathrm{~mA}$ (Alexander et al, 1985).

\section{HASIL DAN PEMBAHASAN}

Ekstrak enzim kasar (crude enzymes) diperoleh dengan sentrifugasi larutan fermentasi $6000 \mathrm{rpm}$ selama 30 menit dan diperoleh larutan enzim kasar $175 \mathrm{ml}$. Terhadap larutan enzim kasar dilakukan uji aktivitas dan didapat aktivitasnya $0,024 \mathrm{unit} / \mathrm{ml}$ di mana satu unit aktivitas didefinisikan sebagai jumlah enzim yang menghasilkan $1 \mathrm{mmol}$ fruktosa/jam dengan kadar protein $37,5 \mathrm{mg} / \mathrm{ml}$.

Terhadap ekstrak enzim kasar dilakukan fraksinasi dengan menggunakan garam ammonium sulfat pada kejenuhan 0-25\%, 25-50\%, 50-75\% dan 75-100\%. Dari hasil fraksinasi ditemukan enzim inulinase berada pada fraksi $50-75 \%$. Endapan hasil fraksinasi ini dilarutkan dalam bufer fosfat $\mathrm{pH} 7$ selanjutnya didialisis selama 24 jam memakai membran semipermiabel (selophan) pada suhu $5^{\circ} \mathrm{C}$ untuk menghilangkan garam yang tersisa pada enzim. Larutan hasil dialisis ini memiliki total aktivitas 0,33 unit dengan kadar protein $42,1 \mathrm{mg} /$ $\mathrm{ml}$.

Pemurnian lebih lanjut dilakukan dengan kromatografi kolom gel filtrasi sephadex G25. Aktivitas inulinase berada pada fraksi 14-18 (Gambar 1), dan dipekatkan menjadi $6 \mathrm{ml}$. Fraksi ini memiliki aktivitas 0.54 unit dan kadar protein $45,8 \mathrm{mg} / \mathrm{ml}$.

Fraksi hasil kromatografi kolom gel filtrasi dimurnikan lebih lanjut dengan kromatografi kolom penukar anion memakai DEAE selulosa sebagai matrik. Fraksi aktif terdapat pada fraksi 40-44 seperti terlihat pada Gambar 2. Fraksi aktif ini dipekatkan kembali menjadi $4 \mathrm{ml}$ dengan aktivitas $0,72 \mathrm{U}$ dan kadar protein $59,8 \mathrm{mg} / \mathrm{ml}$ (Tabel 1). 
Fraksi hasil kromatografi kolom gel filtrasi dimurnikan lebih lanjut dengan kromatografi kolom penukar anion memakai DEAE selulosa sebagai matrik. Fraksi aktif terdapat pada fraksi 40-44 (Gambar 2). Fraksi aktif ini dipekatkan kembali menjadi $4 \mathrm{ml}$ dengan aktivitas $0,72 \mathrm{U}$ dan kadar protein $59,8 \mathrm{mg} / \mathrm{ml}$.

Untuk melihat tingkat kemurnian inulinase yang sedang diisolasi serta berat molekul relatifnya dilakukan dengan elektroforesis gel SDS dengan matrik gel poliakrilamida (SDS PAGE) (Gambar 3). Pada Gambar 3 tersebut setelah dihitung dengan cara

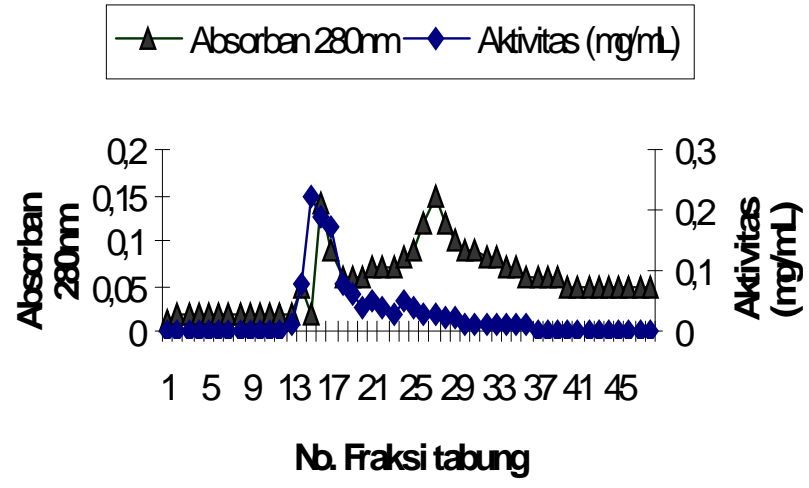

Gambar 1. Kurva pola protein hasil pemisahan inulinase dari $A$. niger Gmn11.1 dengan kromatografi kolom gel filtras sephadex G25

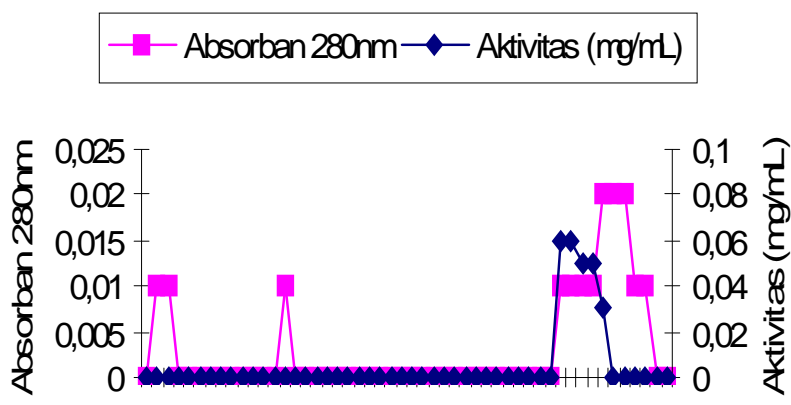

15913172125293337414549

\section{Nb. Fraksi tabung}

Gambar 2. Kurva pola protein hasil pemisahan inulinase dari $A$. niger Gmn11.1 dengan kromatografi kolom penular ion DEAE Selulosa
Isolasi dan karakterisasi enzim inulinase

2
1
2
3
4
5

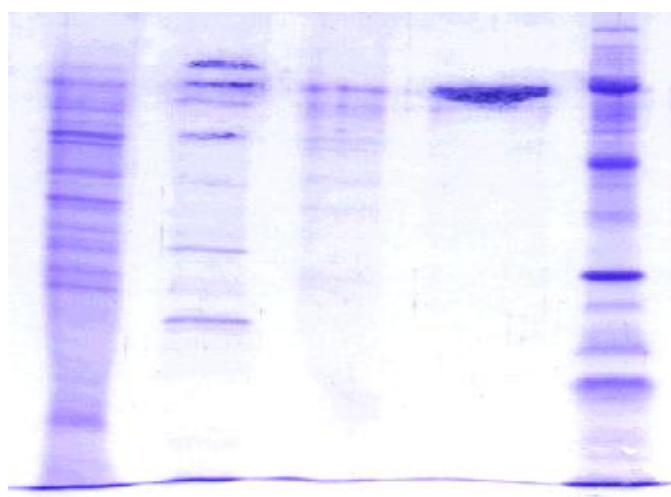

$94 \mathrm{KDa}$

$76 \mathrm{KDa}$

$43 \mathrm{KDa}$

$30 \mathrm{KDa}$

$20,1 \mathrm{KDa}$

$14,4 \mathrm{KDa}$

Gambar 3. Hasil elektroforesis gel SDS: $1=$ Ekstrak kasar; $2=$ Fraksi amonium sulfat; $3=$ fraksi gel filtrasi dan $4=$ fraksi kolom penukar ion, Standar BSA.

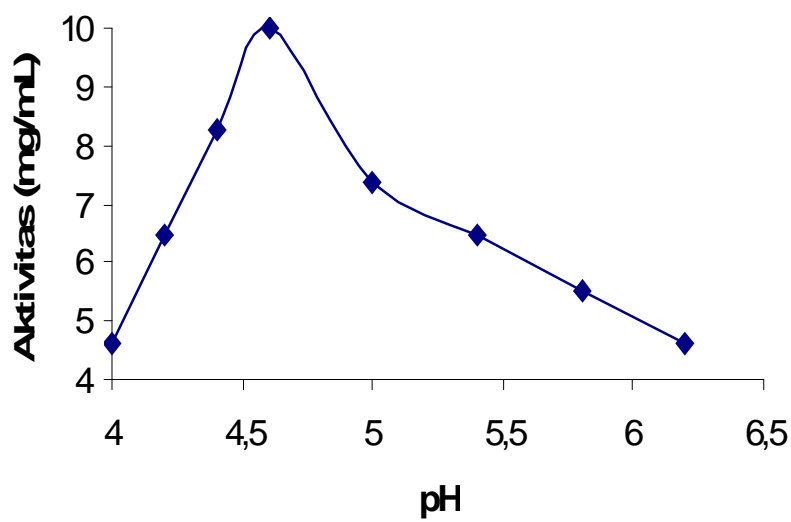

Gambar 4. Kurva hubungan $\mathrm{pH}$ dengan aktivitas inulinase dari A. niger Gmn 11.1

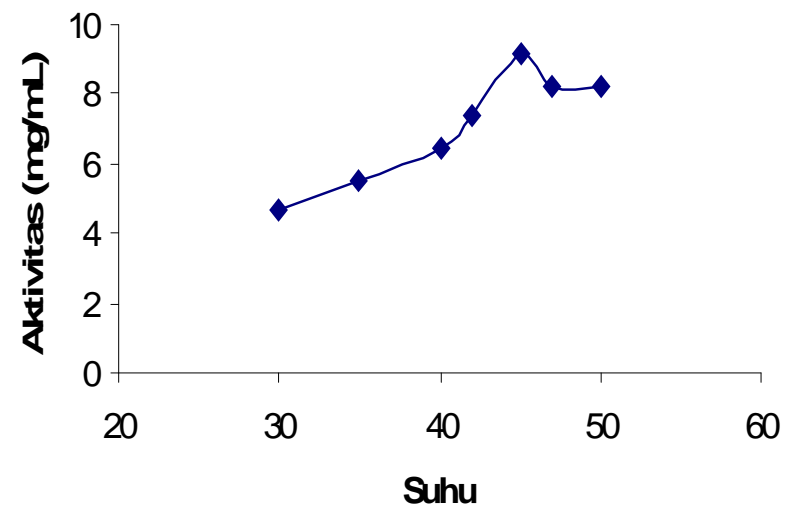

Gambar 5. Kurva hubungan suhu dengan aktivitas inulinase dari A. niger Gmn 11.1

Tabel 1. Skema pemurnian enzim

\begin{tabular}{|c|c|c|c|c|c|c|c|c|}
\hline \multirow[b]{2}{*}{ Tahap } & \multicolumn{3}{|c|}{ Protein } & \multicolumn{5}{|c|}{ Enzym } \\
\hline & $\begin{array}{l}\text { Vol } \\
(\mathrm{ml})\end{array}$ & $\begin{array}{l}\text { Konst. } \\
\mathrm{mg} / \mathrm{ml}\end{array}$ & $\begin{array}{l}\text { Total } \\
(\mathrm{mg})\end{array}$ & $\begin{array}{l}\text { Akt. } \\
\mathrm{U} / \mathrm{ml} \text {. }\end{array}$ & $\begin{array}{c}\text { Akt. Sp } \\
\mathrm{U} / \mathrm{mg} \text { prot. }\end{array}$ & $\begin{array}{l}\text { Total } \\
\text { Unit }\end{array}$ & $\begin{array}{c}\text { Faktor } \\
\text { Kemurnian } \\
\text { (kali) }\end{array}$ & $\begin{array}{l}\text { Peroleh } \\
\text { an (\%) }\end{array}$ \\
\hline Ekstrak kasar & 175 & 37,5 & 6562,5 & 0,024 & 0,0006 & 4,2 & 1,00 & 100 \\
\hline Frak. Am. Sulfat & 10 & 42,1 & 421 & 0,33 & 0,008 & 3,3 & 13,33 & 78,5 \\
\hline Sephadex G25 & 6 & 45,8 & 274,8 & 0,54 & 0,011 & 3,2 & 18,33 & 76,2 \\
\hline DEAE Selulosa & 4 & 59,8 & 239,2 & 0,72 & 0,012 & 2,8 & 20 & 66,6 \\
\hline
\end{tabular}




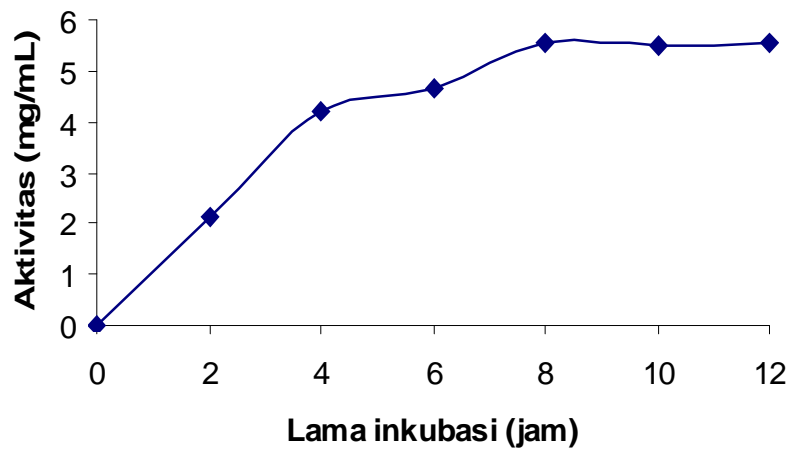

Gambar 6. Kurva hubungan waktu inkubasi dengan aktivitas inulinase dari $A$. niger Gmn 11.1

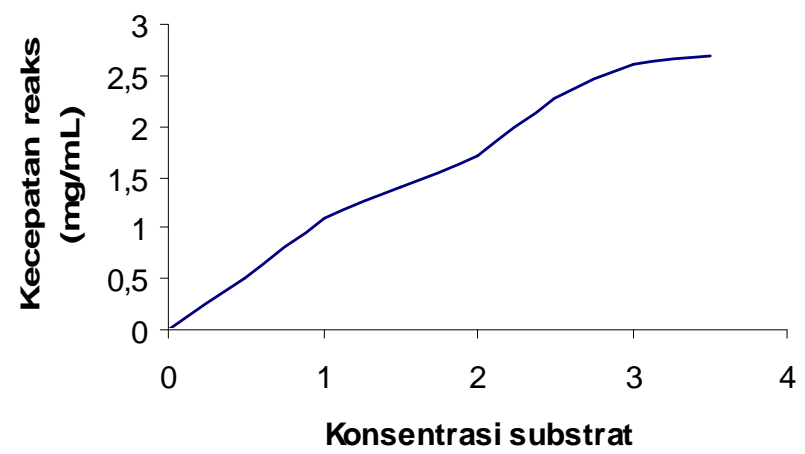

Gambar 7. Kurva pengaruh konsentrasi substrat terhadap kecepatan reaksi inulinase dari $A$. niger Gmn11.1

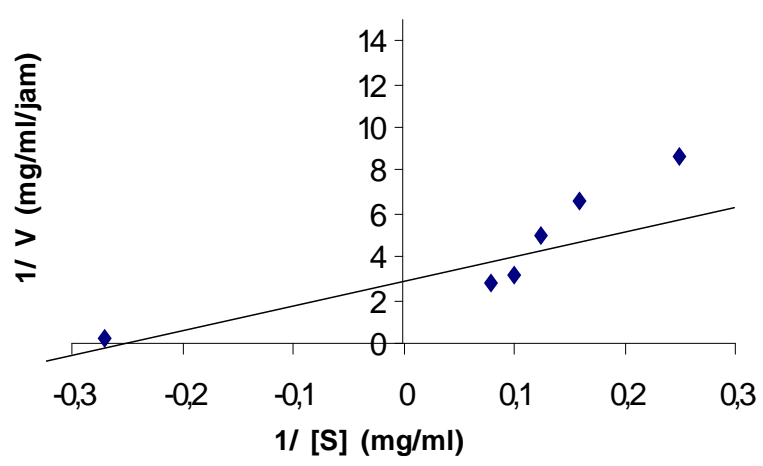

Gambar 8. Kurva pemetaan Lineweaver-Burk yang menggambarkan harga $\mathrm{Km}$ dan Vmaks inulinase dari A. niger Gmn11.1

membandingkannya dengan kurva standar, maka didapat berat molekul relatif dari enulinase yang sedang diisolasi sekitar $63 \mathrm{KDa}$.

Inulinase memiliki aktivitas optimum pada $\mathrm{pH}$ 4,6 dan suhu inkubasi optimum $45^{\circ} \mathrm{C}$ dengan lama inkubasi optimum 15 jam ditunjukkan pada Gambar 4, Gambar 5, dan Gambar 6.

Penetuan parameter kinetika reaksi enzim $\mathrm{Km}$ dan Vmak mendapatkan hasil $20 \mathrm{mg} / \mathrm{ml}$ dan $0,769 \mathrm{mg} / \mathrm{ml} /$ jam seperti dapat terlihat pada Gambar 6.
Enzim inulinase yang dihasilkan oleh Aspergillus niger Gmn11.1 galur lokal ini merupakan enzim ekstraselular, di mana enzim berada di filtrat medium fermentasi. Setelah dilakukan fraksionasi dengan garam amonium sulfat ternyata enzim inulinase berada pada kejenuhan $50-75 \%$.

Enzim hasil fraksionasi ini selanjutnya dimurnikan dengan kromatografi gel filtrasi memakai sephadex G25. Pada pemisahan ini ditemukan fraksi aktif berada pada tabung no 14-18. Hal ini mengindikasikan bahwa enzim yang sedang diisolasi keluar pada awal atau labih dahulu, itu berarti bahwa molekul enzim yang sedang diisolasi lebih besar dari pori-pori gel dan tidak dapat memasuki gel. Hal ini sesuai dengan data literatur bahwa sephadex G25 memiliki pori-pori lebih kecil dari 30.000 Dalton sedangkan data elektroforesis menunjukan berat molekul relatif enzim enulinase yang sedang diisolasi sekitar 63.000 Dalton. Oleh sebab itu agar protein enzim dapat tersaring dengan baik sehingga pemisahan juga akan berjalan dengan lebih baik, maka matrik yang digunakan sebaiknya sephadex $\mathrm{G} 75$ yang dapat menyaring molekul dengan BM antara 30.000-70.000 Dalton.

Fraksi aktif gel filtrasi diatas selanjutnya dimurnikan dengan kromatografi kolom penukar ion dengan matrik DEAE selulosa. Pemisahan ini mendapatkan fraksi aktif pada tabung 40-44. Hal ini membuktikan bahwa enzim mula-mula terikat dulu pada matrik DEAE selulosa dan baru setelah perubahan gradien konsentrasi enzimnya kembali lepas dan keluar, dengan konduktifitas sekitar 4000-4500 micromho/cm. Karena DEAE selulosa suatu matrik yang bermuatan negatif atau penukar anion, maka ini membuktikan bahwa enzim inulinase yang sedang diisolasi bermuatan positif

Enzim dari setiap tahap pemisahan dielektroforesis untuk melihat pola proteinnya seperti terlihat pada Gambar 3 dimana fraksi dari kromatografi kolom penukar ion telah memperlihatkan satu pita dengan berat molekul relatif $63 \mathrm{KDa}$. Kazutomo et al, (1990) dan Manzoni \& Cavazzoni (1991) juga telah melaporkan bahwa inulinase ekstraselular dari Arthrobacter globoformis S64-1 dan Kluyveromices cicerisporus memiliki berat molekul $100 \mathrm{KDa}$, sedangkan laporan lain juga ada yang melaporkan berat molekul inulinase 70 dan $180 \mathrm{KDa}$. Data ini mengindikasikan bahwa berat molekul inulinase sangat bervariasi. Namun demikian 
utuk melihat kemurnian enzim yang diisolasi secara lebih detil, masih perlu diperikasa lagi dengan peralatan yang lebih sensitif seperti HPLC fasa terbalik. Hal ini perlu dilakukan sebelum kita melakukan pemuliaan lebih lanjut terhadap molekul enzim agar dihasilkan suatu enzim yang memilki arti ekonomis. Sebab walau enzim hasil pemurnian ini telah memiliki aktivitas $0,72 U$ yang berarti 30 kali lebih tinggi dari ekstrak enzim kasar 0.024 Unit, tapi dari data kinetika reaksinya terlihat spesifisitas enzim ini masih terlalu rendah terhadap substratnya.

Inulinase ekstraselular ini memiliki pH optimum 4,6, suhu optimum $45^{\circ} \mathrm{C}$ dengan lama inkubasi 15 jam. Nilai $\mathrm{Km}$ dan Vmak untuk enzim ini masing-masing $20 \mathrm{mg} / \mathrm{ml}$ dan $0,769 \mathrm{mg}$ fruktosa/ml/jam. Data ini memperlihatkan kerja enzim ini dalam menghidrolisis inulin menjadi fruktosa masih sangat lambat, seperti lama inkubasi 15 jam dan nilai $\mathrm{Km}$ yang masih cukup besar dan Vmak nya masih relatif kecil. Sungguhpun demikian informasi dari hasil penelitian ini sangat berguna untuk proses pemuliaan lebih lanjut untuk mendapatkan enzim yang lebih produktif. Apakah melalui pendekatan modifikasi protein enzim atau melalui rekaya genetika. Sebab secara umum enzim yang dihasilkan secara alamiah memang masih memilki aktivitas rendah, enzim-enzim yang berada dipasaran umumnya berasal dari galur yang telah dimodifikasi baik secara fisik maupun kimiawi.

\section{KESIMPULAN}

Kapang Aspergillus niger Gmn11.1 yang diisolasi dari umbi dahlia dapat menghasilkan enzim inulinase ekstraselular dengan berat molekul sekitar 63.000 dalton. Enzim ini bekerja pada pH optimum 4,6 suhu optimum $45^{\circ} \mathrm{C}$ dengan lama inkubasi 15 jam.

Walaupun aktivitas enzim telah meningkat dari 0,24 unit pada ekstrak kasar menjadi 0,72 unit setelah pemurnian (30 kali). Namun dari hasil perhitungan kinetika reaksinya enzim inulinase ini memiliki nilai $\mathrm{Km}$ $20 \mathrm{mg} / \mathrm{ml}$ dan Vmak $0,697 \mathrm{mg} / \mathrm{ml} / \mathrm{jam}$. Data ini memperlihatkan spesifisitas atau aktivitas enzim masih rendah terhadap substratnya, terlihat dari nilai Km yang masih besar sedangkan Vmaknya kecil. Namun demikian informasi ini sangat berguna untuk pengembangan penelitian selanjutnya, khususnya dalam rangka mempelajari sifat-sifat fisikokimia dari enzim secara lebih detil. Hal ini sangat diperlukan untuk pemuliaan molekul enzim kearah yang lebih menguntungkan, seperti melalui modifikasi kimiawi atau genetikanya.

\section{UCAPAN TERIMA KASIH}

Terima kasih disampaikan kepada Dr. Ukun MS Soedjanaatmaja, MS Dosen Biokimia FMIPA UNPAD dan Laboratorium Biokimia Jurusan Kimia FMIPA UNPAD atas bantuannya baik moril maupun fasilitas yang digunakan untuk penelitian.

\section{DAFTAR PUSTAKA}

Alexander R. R., J. M. Griffiths \& M. L. Wilkinson. 1985 Basic Biochemical Methods. Singapore: John Willey \& Sons.

Beatrice, L. Pool_Zobel. 2005. Inulin-type fructan and reduction in colon cancer risk: review of experimental and human data. British Journal of Nutrition 93: 573-590

Gupta A.K., M.Kaur, N. Kaur, \& R. Singh. 1992. A comparison of properties of Inulinase of Fusarium oxysporum immobilized on various supports. Journal Chem. Tech. Biotechnology 53:293-296.

Gilbert A. 1957. Colorimetrict Analysis Of Sugar. Method in Enzymology. Vol. III. New York: Academic Press, Inc.

Kazutomo, H., Hayashi K., \& Kasumi T. 1990. Purification and properties of inulinase from Arthrobacter globoformis S641. Starch 42(1): $28-30$

Lowry, O. H., N. J. Rosenbrough, A. L. Farr \& J. R. Randall. 1951. Protein Measurement with Folin Phenol Reagent. J. Biol. Chem. 193: 265-275.

M. Belmari. 1994. Purification and properties of an extracellular inulinase like $\beta$-Fructosidases from Bacillus stearothermophylus. Letter Applied Microboal 19(6):410 413

M. manzoni \& Cavazzoni V. 1991. Purification and caracterization of sxtracellular inulinase from Kluyveromices cicerisporus. Lebensm-Wiss Tecnology, England 24(3):236-240.

Nakamura T., Y. Ogata, A. Shitasa, A. Nakamura \& K. Ohta. 1995. Continuous production of fructose syrups from Inulin by immobilized inulinase from Aspergillus niger Mutan 817. J. of Fermentation and Bioeng. 80(2): 164-169.

Roberfroid M. B. \& N. M. Dezenne. 1998. Dietary fructans Annu. Rev. Nutrition 18: 117-143.

Saryono, Henny Olivia R. M., Elvita Sepriana, Andi Dahliati, \& Chainulfiffah A. M. 2008. Amobilisasi inulinase Aspergillus clavatus Gmn11.3 galur lokal Indonesia. Jurnal Natur Indonesia 10(1): 31-35

Saryono, Chainulfiffah A. M., Silvera Devi Sy., Monalisa H.S., \& Dasli. 1998. Pemanfaatkan umbi dahlia (Dahlia variabilis) untuk produksi sirup fruktosa (HFS) dan fruktooligosakarida”. Seminar Nasional PBBMI XIV. Bandung.

Saryono, Is Sulistyati P. \& Delita Zul. 1997. Identifikasi Jamur Pemecah Inulin pada Umbi Dahlia. Pekanbaru: Lembaga Penelitian Univ. Riau,

Vandamme E. J., \& D. G. Derycke. 1983, Microbial inulinase: fermentationprocess, properties and applications. Advances in Appl. Micro. 29: 139-176.

Workman W.E. \& D.F.Day. 1983, Enzymatichydrolysis of Inulin tofructose by glutaral dehyde fixed yeast cell. Biotech. \& Bioeng. XXVIII:905-910

Zeily N, Ukun MS Soedjanaatmadja, \& Abubakar Sidik. 1991 Penuntun Praktikum Biokimia Lanjut. PAU Bioteknologi ITB. Bandung: ITB 